\title{
“Choose One!”: Challenges of Inter-Ethnic Marriages in Malaysia
}

\author{
Giok Hun Pue ${ }^{1} \&$ Nidzam Sulaiman ${ }^{1}$ \\ ${ }^{1}$ Institute of Ethnic Studies (KITA), Universiti Kebangsaan Malaysia, Bangi, Selangor, Malaysia \\ Correspondence: Giok Hun Pue, Institute of Ethnic Studies (KITA), Universiti Kebangsaan Malaysia, Level 4, \\ Administration Building, Kolej Keris Mas, 43600 Bangi, Selangor, Malaysia. Tel: 60-3-8921-7682. E-mail: \\ ghpue@hotmail.com
}

Received: September 5, 2013 Accepted: September 29, 2013 Online Published: November 29, 2013

doi:10.5539/ass.v9n17p269 URL: http://dx.doi.org/10.5539/ass.v9n17p269

\begin{abstract}
The fact that inter-ethnic marriage has been practiced in Malaysia since pre-colonial times is well known and recorded in its history. While there is a modest rise in number of people who choose to marry spouses from different ethnic group in the country, the practice itself has been generally portrayed as a problematic and wanting especially in the Peninsular Malaysia. Popular writings and mass media play a significant role in stereotyping the phenomenon as a current modern (read: western)-influenced trend in contemporary society, as well as its potential to create tensions between the spouses due to their differences in ethnic background and culture. Based on our qualitative study conducted in 2011 on 50 respondents with first-hand experience in inter-ethnic marriages, this paper argues that sources of conflict faced by the couples are not originated from spouses themselves. Instead, they were initiated by various external sources which stem from overwhelming dominance of authority-defined social reality in the organisation of social differences according to rigid ethnic lines in the society. As a result, positive effects of inter-ethnic marriages on maintaining social cohesion in the society, as reflected from first-hand experiences of spouses and progeny of inter-ethnic marriages, are affectively eclipsed.
\end{abstract}

Keywords: inter-ethnic marriages, Malaysia, social cohesion, qualitative study, authority-defined social reality

\section{Introduction}

The practice of inter-ethnic marriages in Malaysia as part and parcel of the society is evident in the existence of Peranakan communities whose ethnic group formation stemmed from long-term, intense assimilation process that was catalysed by inter-ethnic marriage between non-native and native ethnic groups (Note 1). Out of the context of Peranakan communities, the phenomenon has been under-studied and under-documented by the government and scholars alike. Thus, general description and perception of the phenomenon among Malaysian society is, at best, mixed. Positive perspective views inter-ethnic marriages as beneficial in contributing towards social cohesion in the society, creating new generations that are more open towards others of different ethnic backgrounds, as well as possibility of producing progeny who are more advantageous in terms of intelligence, beauty, emotional and behavioural stability (Tan, 2012; Zainon, 2005). However, positive perception of inter-ethnic marriage tends to be over-shadowed by negative perception. This is mainly due to influence from popular writing and media coverage that sensationalise selected cases of high profile inter-ethnic marriages among celebrities, public figures as well as controversial and lengthy court cases. As a result, inter-marriage is portrayed as problematic and wanting practice that is troublesome and short-lived (Minuddin, 2005; Zakaria, 2010; Jalil, 2010). Negative perception towards inter-ethnic marriage is more apparent when it involves conversion of religion as part of the requirement for the marriage to take place. In particular, Muslim-non-Muslim marriage in Malaysia is seen as notorious due to political and legal contestation between Islamic Syariah laws and civil laws (Lindenberg, 2009; Mohamad, Aziz \& Oy, 2009; Hak, 2012; Sintang, Khambali, Baharuddin \& Ahmad, 2011). Due to its seemingly conflict-prone nature, greater problem in marital relationship are recorded among inter-ethnic marriages than mono-ethnic marriages, such as low marital satisfaction and higher rate of conflict (Ismail, 2003; Baharuddin, Juhari \& Tan, 2003). Based on 1981 Marriage Survey, Tan (1989) finds that majority of Malaysian society that transcends gender and ethnic groups agree that inter-ethnic marriage should not be encouraged. Such view still echoes in Malaysian society 30 years later (Jalil, 2010; Minuddin, 2005). 
In spite of the mixed perceptions, scholars believed that the trend of inter-ethnic marriage in Malaysia is on the rise (Osman, 1981; Chong, 2009; Nagaraj, 2009). Nagaraj's (2009) analysis based on two per cent sample of the 2000 Population Census, finds that 4.6 per cent of marriages in Malaysia involve spouses from different ethnic groups. Although small in number, it is an increase from about 0.5 per cent as suggested by Malaysian Fertility and Family Survey conducted in the Peninsular in 1974 (Tan, 1989, p. 235). Geography-wise, inter-ethnic marriage is a practice more commonly found in Sabah and Sarawak as oppose to the Peninsular. In terms of percentage, this could be translated into 11.6 per cent and 3 per cent of marriages in West Malaysia and Peninsular Malaysia respectively in 2000 (Nagaraj, 2009). When examined further, higher number of inter-ethnic marriages is found concentrated in regions and major urban growth centres whereby social distances between ethnic groups are shorter. This includes Sabah, Sarawak and Labuan in West Malaysia, and Kuala Lumpur and urban areas of Selangor in the Peninsular (Chong, 2009; Nagaraj, 2009). Osman (1981) observes that there is an upward trend in the practice of inter-ethnic marriage in Bandar Melaka, Melaka among his respondents as compared to their parents' generation. Alternatively, Chong (2009) suggests the emergence of new social concepts used as labels in reference to progeny of specific types of inter-ethnic marriages also denotes upward trend of the practice. The social concepts are made of pairs of ethnic ethnonyms joined together in hyphenated or conjoint form such as "Chindian" (Chinese-Indian), "Chiban" (Chinese-Iban), "BawangCina" (Lumbawang-Chinese) and "Sinokadazan" (Chinese-Kadazan). Although most of the concepts are more commonly used in West Malaysia, some concepts including Chindian and Sinokadazan are well understood by Malaysian society in general. The concept of Chindian, in particular, is also common in the Peninsular (Ang \& Shik, 2010; Mac \& Zaid, 2010).

While more studies are generated as a result from the upward trend of inter-ethnic marriage phenomenon in the society, they tend to focus on interpersonal relations and socio-cultural (and religious) attributes between spouses as well as with close family members. However, we argue that sources of conflict in inter-ethnic marriage are not originated from incompatibility of spouses as husband and wife, but from third parties who are outsiders of the marriage, i.e., the society itself. Here, the present paper explores interaction between husband and wife as a couple (insider) vis-à-vis other actors such as other family members, community members or public, as well as related government bodies (outsiders).

\section{Method}

Funded by National Unity and Integration Department (JPNIN) under Prime Minister's Department, the study was conducted between January and December 2011. The scope of the study was limited to inter-ethnic marriages between spouses who are both Malaysian citizens. Data were collected through several qualitative methods, viz., in-depth and focus group interviews with 50 respondents who were directly involved in inter-ethnic marriages namely the husbands, wives, and/or adult children of such marriages from Kota Kinabalu in Sabah, and several regions in the Peninsular including Butterworth and Prai in Penang, Kampar and Setiawan in Perak, Bandar Baru Bangi in Selangor, and Kota Bharu and Tumpat in Kelantan. Respondents were identified and selected via snowball technique. The researchers solicited assistance from colleagues, family members and friends to introduce to them individuals who are directly involved in inter-ethnic marriages within their personal capacities. Those who agreed to participate in the study then introduced other potential respondents from their personal circle of friends or family members to the researchers. Data from respondents who shared similar association were gathered via focus group interview. The technique was conducted twice throughout the study, first with 20 respondents who are Universiti Malaysia Sabah (UMS) employees, and second with 10 members of Malaysian Chinese Muslim Association (MACMA) of Kelantan branch in Kota Bharu. In addition, a forum was held on September $20^{\text {th }}$ to encourage open dialogue between three panel members who were involved in inter-ethnic marriage and the public. All dialogues were recorded with permissions from the respondents, and subsequently transcribed. The transcripts were read and re-read as part of the analysis to identify common, recurring themes that exist within the data.

\section{Findings and Discussion}

Due to the snowball technique employed, majority of the respondents were from middle-class level. Only three respondents could be classified as from lower-class level in terms of employment. Similarly, all respondents reported that they were still married to the same spouse except for three respondents whose marriage ended in divorce. Marriage spans ranged from three to 38 years among respondents whose age between 32 to 58 years old.

When asked for general description of their marriage in terms of quality of relationship with spouse, overall respondents in the study reported as successful. They believed that their inter-ethnic marriages went through the 
same adjustment phase particularly in the beginning of married life, which was not dissimilar to what couples of mono-ethnic marriages went through. Even among the respondents who were divorced, ethnic difference was not regarded as a crucial problem in their relationship with their spouse. Differences in terms of cultural practices such as language, code of dressing, food and cultural celebrations were learnt and subsequently negotiated to suit each other's needs. In the context of Malay-non-Malay inter-ethnic marriages, most couples adhere to Muslim-Malay culture which is the dominant culture. However, cultural elements from non-Malay spouse were integrated to a varying degree, into their family's cultural practice, provided that the elements did not conflict with Islamic teachings. Among common non-Malay cultural elements practiced in Muslim-non-Muslim marriage were the practice of language, food, and festive cultural practices such as distributing and receiving goodies including angpow, duit raya, biscuits, ketupat, gift hampers and oranges.

However, when asked to describe their inter-ethnic marriage in terms of quality of interaction with wider society, different pattern of responds emerged from respondents in the Peninsular vis-à-vis in Sabah. The latter's resounding answers were positive. This is contributed by, among others, inter-ethnic marriage being an acknowledged common practice among different ethnic groups in the society, supported by a healthy mixture of ethnic backgrounds within a single residential area, as well as the utilisation of Malay language as lingua franca among different ethnic groups. High tolerance level within inter-ethnic relationship could be seen whereby cultures of both spouses were understood, respected and followed via accommodation strategy. For example, it is common practice to enforce "sogit" as a type of penalty to outsiders who wanted to marry members of native group such as Dusun according to their traditional customs. Prior to marrying his Dusun wife, a respondent of Brunei-Malay descent was requested a pig as sogit by her family. Due to his Islamic beliefs, the respondent could not fulfill the sogit literally. Thus, he gave his future parent-in-laws money that amounted to a pig's value instead. Similar positive responds were extended to governance practice, particularly with regards to Islamic authoritative bodies. Stringent enforcement was not practiced by such bodies. This allowed ample time for non-Muslims who converted to Islam to immerse into the religion according to their own personal pace. They also did not feel pressured to abandon their traditional customs or original ethnic identity that do not contradict the religion altogether.

Taking this into consideration, this section of the present paper focuses on challenges in the practice of inter-ethnic marriage in the Peninsular. The study has identified three main area of challenges, namely intervention from third party within family circle, stereotype and prejudice by mainstream society and legislative and bureaucratic dilemma.

\subsection{Intervention from Third Party within Family Circle}

As inter-ethnic marriages rooted in love marriage, spouses were found to have understood and accepted each other's ethnic differences and at the same time, made a conscious effort to overcome any ethnic barrier that might exist. Problem began to arise when they expressed their wish to marry their partner to their parents and family in general. Challenges in this context tend to come from mothers instead of fathers, especially when it concerned of daughters. Other than taking socio-economic background of their child's partner into consideration of the person's worthiness, parents' reactions were also guided by negative ethnic stereotype commonly associated with ethnic group whose their child's partner is a member. A female respondent of Chinese descent was advised against accepting her boyfriend of Thai descent by her mother on the basis that Thai men tend to be drunkard, and malicious. Similarly, Malays were perceived to be lazy, laidback and hypocrite. The following comment made by a male respondent of Chinese descent who has been married to a Malay woman for 28 years, illustrates the concern on the issue:

My parents were furious (on my wish to get married to Malay woman) because they said that the Malays, as claimed by the Malays themselves, are lazy in doing work. Every day (they) patronise coffee shop, and during fasting season, discreetly eating rice at a shop behind (our) house. From such attitude they build up such perception. That's why they got angry (at me).

However, objection by parents and family tended to subside quickly among inter-ethnic marriage that did not involve religious conversion as well as marriages between spouses from two culturally compatible ethnic groups. This pattern was found among our respondents of Chinese-Indian inter-ethnic marriages among Christian devotees in Selangor and Chinese-Thai inter-ethnic marriages in Kelantan. In the latter, Peranakan Chinese culture that was highly influenced by elements of local cultures in Kelantan, were found to share a high degree of similarities in terms of cultural practices as well as religious belief. In addition, inter-ethnic marriage has been practiced between both ethnic groups since before time, thus the practice is easily accepted and acknowledged within local community. Whereas for Chinese-Indian couples who embrace Christianity, shared religion 
influenced way of life for both partners, thus superseded other cultural differences that existed between both ethnic groups. Hence, the research found that such type of inter-ethnic marriage faced minimal challenges from parents and family circle.

Challenges from third party within family circle escalated in intensity when it involved spouses from two ethnic groups whose ethnicity elements were incompatible or stark different with one another. This was often found among our respondents who were involved in Muslim-non-Muslim marriage between Malay and non-Malay descents. It occurred regardless the reason for conversion was for marriage or religious purposes. In this context, inter-ethnic marriage problem occurred in tandem with conflict that was raised from the act of religious conversion itself. This stemmed from concerns that religious conversion would have unwanted consequences between the individual and one's parents and family members.

Firstly, non-Malays were reserved in their perception of Islam. By converting to Islam, non-Malay parents feared that their offspring would be facing hard lives due to a comparatively stricter religious practices as required in the religion, such as conducting prayers five times a day, fasting from dawn to dusk during fasting month of Ramadhan and constant abstinence from alcoholic beverage and forbidden food. In addition to these requirements, daughters who wanted to convert her religion to Islam faced stronger objection than sons. This is due to parents' concern that their daughter's marital life could be jeopardised should their future husbands take more than one wife as permitted by Islamic teachings. The following quote by a female Muslim respondent of Chinese descent whose husband of 17 years is a Malay man, illustrated the concern of the issue commonly voiced out by female Muslim respondents of non-Malay descents:

(my father) did not object (to my wish to convert to Islam). It's just that, he fears that, as Islam religion allows the husband to take (up to) four wives...that was his main point: four wives. It would've been fine if (the husband) is fair and equal, but (father) was concerned if (the husband) takes wife number two, and wife number one would be thoroughly neglected.

Concomitantly, the second concern that pushes the non-Malay family members to strongly oppose conversion to Islam was from fear that the individual who converted to Islam would denounce his or her original religion, and subsequently disdain family members as infidels. This was indicated by comments similar to the following as expressed by a male Muslim respondent of Thai descent and has been married to a Malay woman for 13 years:

(When I expressed my wish to embrace Islam), my father said nothing, (but not) my mother. She was very sad to the verge of committing suicide. (She) went into the room and refused to come out for weeks, even after I went back and tried coaxing her to come out. (Afterwards) my father consented and said that being an adult, I should be able to make my own decision, (but) had one (request) that I do not denounce my own family.

Concerns and fears by parents and family members regarding conversion to Islam and Malay-non-Malay inter-ethnic marriage were resulted in negative stereotypes fed to them by other community or family members. For instance, a female respondent of Chinese descent recalled her plan to embrace Islam was met with strong objection from her mother after she was informed by one of the Malay neighbours that it would mean their mother-daughter relation severed indefinitely. According to another respondent who was in the MACMA community member, such incident has been infamously common among non-Malay families in recent past, thus it is understandable that parents were anxious to avoid similar tragedy to occur in their family.

The study also found that contestations between non-Malay family members particularly among the Chinese, tend to cease significantly after a baby was born by the inter-ethnic couple. This was in line with Chinese mind-set that revolves around sustaining family lineage. Aside from birth of new generation, it was common enough for both parties to initiate efforts to rekindle their family ties after a period of time, particularly by fathers whose opinion on inter-ethnic marriage and religious conversion by their children were more neutral in comparison to mothers.

When asked about their experience with their Malay in-law families, non-Malay respondents believed that it has been generally fine although somewhat cold in comparison to treatment they received from their own families. The study found that Malays were less welcoming towards their in-laws who were converts instead of being born a Muslim as well as their non-Malay lineage. In other words, they were often ill-equipped in facilitating new member who was non-Malay into their family. Examples of comments made by two female respondents (the former is of Chinese descent and married for 17 years to a Malay man, and the latter is a divorcee of Orang Asli (indigenous) descent and was married to a Malay man for 5 years) below, illustrate severity of the situation as noted by two respondents from different ethnic backgrounds:

When my family invited his family to come over for a feast, they came but (acted like) guests instead of 
(extended family members)...their attitude lack of something special. Whilst my father presented my husband, son and daughters presents as show of affection, there is no such thing from his side (of the family), they came for the sake of coming. From there I saw that I was treated as an outsider, and that really hurts. So they treat me as of no value. It hurts because I have given my best effort, but is still treated so.

My family-in-law denigrated me...everything I did was wrong. When I wore pretty clothes, they said that I tried to be a Malay. Yet when I did not wear a headscarf, they still criticised me...They looked down and 'demonise' Orang Asli. They said that when my husband visited my parents, he was served with plates that were used to serve pork... When my mother shook hands with his mother, she (husband's mother) did so after covering her hand, as if my mother was filthy. But other people said that my mother-in-law was a good person, (so) maybe I was unfortunate.

Their status as convert of non-Malay ethnicity presented a disposition among Malay family whereby they were perceived to be inferior to other family members. As such, they were expected to be at the receiving end of the relationship. The following comment made by a female respondent of Chinese descent who has been married to a Malay man for 38 years illustrates how an effort by a non-Malay Muslim respondent to guide her religiously-slacking family-in-laws back to the correct path of Islam was met with hostility in return:

My husband's family, although being born as Muslim, unfortunately up to this day, have not been practicing Islam diligently in the case of conducting prayers and fasting, for example. Acting on the advice of a mufti, I asked them to repent. When I did so, they were very furious with me. I'm the convert one, yet asked them to conduct their prayers. It was as if an atomic bomb had exploded. Before that, our relationship was fine, even privileged as my husband was their eldest child. After that incident, I could not even pay them a visit for a year. Our relation only improved gradually when after it was mollified by my husband by taking his problematic youngest brother into our care.

\subsection{Stereotype and Prejudice by Mainstream Society towards Inter-Ethnic Marriages}

For non-Malay Muslim converts, what occurred within Malay family with regards to their relation with their non-Malay family member, mirrored one of many challenges faced by inter-ethnic couples and their progeny in their relationship with mainstream society in the Peninsular Malaysia, whereby it became synonymous with "becoming a Malay" or "masuk Melayu" mind-set. This well-known mindset stems from the constitutional fact that being a Muslim is one of three main characters of Malay identity in Malaysia (Shamsul, 1999). Feeding on the status of Muslim-Malays as the majority ethnic group in the Peninsular, it created a popular albeit misleading impression that the act of embracing Islam was akin to becoming Malay. Thus, when Muslim converts among non-Malay ethnic groups adopted new cultural practices such as donning baju Melayu, songkok or skullcap to reflect their newfound religion, they were often met with negative remarks from the Malay community who perceive such practices as conscious effort to become Malay. As a convert male respondent who is of Thai descent and has been married to a Malay woman for 13 years commented:

In the beginning it was hard. 'Wow, you look so pious', they often teased. Even by wearing a skullcap like this one, I was teased as trying to be pious. So, in the beginning, I felt very much censured.

On the other hand as Islam being synonymous with Malayness, there is a general perception in mainstream society whereby everybody whose physical characteristics are Malay-ish, are Muslim, and likewise non-Malay are automatically assumed as non-Muslim. Such stereotype was not applicable only among laymen but authoritative officers on duty as well as reflected in the following comment made by a male Muslim respondent of Chinese descent and has been married for 24 years to a Malay woman:

There was a time when I attended a tahlil (religious ceremony) wearing baju Melayu and skullcap. Afterwards, I was stopped by a police sergeant. He said, ‘you Chinese, why you wear like this?' even when I showed him my identification card...he thought that (it was because) I wanted to avoid wearing a helmet while riding my motorcycle.

In addition, Muslim respondents of non-Malay descent often found themselves criticised when practicing non-Malay cultural elements that were not against Islamic teachings, such as using chopsticks which is synonymous with Chinese eating culture or greeting extended family members on Thai descent in the form of "wai" (a slight bow, with the palms joined together forming a lotus shape and placed above the chest) following Thai culture. It was not uncommon to find among the Malays who perceive any cultural elements of non-Malay ethnicity as haram (forbidden) by default.

Such narrow and superficial interpretation on what is and what is not Muslim-Malays do not necessarily involved Malay-non-Malay inter-ethnic marriages but also between couples from different non-Malay ethnic 
backgrounds such as Chinese and Indian or Chinese or Thai. In particular, it becomes more problematic and persistently tortuous on everyday basis for progeny of such inter-ethnic marriages. Their phenotype and cultural practices such as fluency in Malay language were commonly associated with Malayness. Thus they did not conform to stereotypes typically associated with any non-Malay ethnic groups such as Chinese or Indian as their parents might be. During a family outing with inter-ethnic spouses and children, they were commonly met with questioning or amused looks, snickers and blatant stares from public. There were even strangers who approached the family to ask whether they were indeed biologically related, as highlighted in comments of some respondents. Even when they operate as lone individual, progeny of inter-ethnic marriage were greeted by perplexed look when interacting with strangers in public settings. In mundane settings, such as a visit to a clinic or being stopped while driving, would often put them ill at ease when the nurse, assistant or traffic police officer would try to scrutinise and probe in order to make sure that the person standing in front of him or her was indeed the owner of the medical or driver's license card in question. This was indicated by comments similar to the following made by a male respondent of Indian descent and has been married to a Chinese woman for 33 years:

Our kids always had problems during puasa time, because people come and tell them 'you are sinned', and scold them, and things like that (for not fasting). Many of kids at school wear baju kurung, so the girls especially, they look very Malay. And they're speaking Malay like Malays, and not like Indians speaking Malay, or Chinese speaking Malay.

Similarly, this study found that progeny of inter-ethnic marriage were not readily accepted as member of an ethnic group by fellow members. Such negative prejudice stemmed on the grounds that they were not 'pure' enough in terms of physical appearance or cultural practices as noted in the following comment of a female respondent of Indian and Chinese descent:

My inability to speak in Chinese made the Chinese students at my school think that I was not a pure Chinese. Indeed, I was perceived to be an Indian student. Difference in language became a barrier for me to befriend Chinese students at that time...(on the other hand, I) actively participated in co-curriculum activities whereby I used to represent my school in competitions based on language skill whether in Malay or English. However, I was not given any chance to participate in any competition conducted in Tamil language. I was aware that some of the teachers at school who thought that I was not Indian enough to participate in the activities.

\subsection{Legislative and Bureaucratic Double Whammy}

Challenges faced by inter-ethnic marriages did not only occur in interpersonal relation but also in the related legislative aspects of practicing inter-ethnic marriage. One clear challenge in this aspect is in the practice of categorising members of a society into rigid mono-ethnic categories. In Peninsular Malaysia, such silo approach over-stresses and over-generalises three main ethnic categories, namely Malay, Chinese and India. The terms Malay, Chinese and India are subsequently used to label and associate its members with a blanketed default ethnic identity that are supposedly unique from other ethnic identities. This includes wearing headscarf as an exclusive marker for Malays and not for Chinese although both are Muslim (Phang, 2011). Within such social landscape, couples of inter-ethnic marriages and their family are expected to operate and identify with one of ethnic identity and not a combination of two or more ethnic identities. In the case of ethnic categorisation for offspring of inter-ethnic marriages, it would usually be traditionally determined by following husband's ethnicity as in patrilineal system. However, it does not reflect fusion of cultural elements from both sides within socialisation process, as well as phenotype of the children of inter-ethnic marriages. As such, many progeny of inter-ethnic marriages face identity crisis whereby they don't feel like they belong to the particular ethnic category. Social concepts such as Peranakan, Malay-Thai, Chindians or its hyphenated form Chinese-Indian that were commonly found in everyday life and arguably more accurate in describing their identities, were not recognised at the official level of governance. One of our Chinese female respondents who married to an Indian man, recalled the effort to not register their new-born baby as neither Chinese nor Indian and instead of another different term, failed in vain after the application was rejected by National Registration Department. In the end, the couple was made to choose between identifying their baby as Indian or Chinese by the department.

In the context of Malay-non-Malay marriage, due to the "masuk Melayu" mind-set, non-Malay Muslim respondents are socially pressured to change their names in to new Malay-style names that ends with "bin" or "binti" Abdullah that literally means 'son or daughter of Abdullah' (servant of God). This is despite that it is not required neither by religion nor conventional laws to do so (Phang, 2011). In this context, respondents in the study often found themselves obfuscated by bureaucratic limbo. Although the related legislation was found to be clear and direct, the implementation of the legislation at the bureaucratic level was anything but. Instead, the implementation often depended on the discretion of officers who happens to handle the case as per case-by-case 
basis. In this sense, lack of clear protocol to guide the procedure is seriously lacking. This is apparent in the vagueness on the requirement for converts to change their name concomitantly with conversion to Islam. The study found that the procedure of the process was not clear cut either. This was highlighted in two particular incidents as experienced by two respondents in the study. In first incident, a Muslim female respondent of Chinese descent was required by an officer at National Registration Department to take an oath as part of the process of registering her new name after converted to Islam in 1990. She was asked to read out loud the content of the oath as written on a piece of paper, which among others stated that she is now has embraced Islam and would no longer use her original name. However, the respondent herself admitted that she had never heard other converts having to go through the same process before or after her time. The second incident occurred to a Muslim male respondent of Chinese descent who converted to Islam in 1974. When he was trying to register his new-born baby's name at a hospital in 1990s, the registrar in charge insisted that the respondent must put a Chinese name as part of his baby's name although the respondent himself has no Chinese name in his post-conversion name.

Couples and children of inter-ethnic marriage also face legislative and bureaucratic dilemma in terms of lack of government agencies to serve as neutral reference centre in offering guidance or consultation pertaining to issues that involve inter-ethnic marriage exclusively. Presently, such functions fall under the jurisdiction of religious bodies instead of under government department directly. While the religious bodies do offer such service, they do not cater the needs of inter-ethnic couples per se but opens to all followers of the religion. In addition, the government agencies or religious bodies tend to be bias towards certain party in the marriage. Muslim respondents in the study were found to be familiar with such as practice by related religious body that tend to give favourable judgment to male than to female, as well as to individuals who are Muslim by birth than converts.

\section{Concluding Remarks}

The findings reveal that although the inter-ethnic marriage is beneficial in promoting social cohesion in the society, the practice is marred by many challenges. The present paper has established that sources of the challenges did not come from ethnic-based incompatibility between spouses as husband and wife, but from various social actors in the society itself. Three main groups of social actors outside of inter-ethnic marriage were identified: 1) third party within family circle such as parents and extended relatives; 2) general social actors in mainstream society that exist within the couple's social space, such as community members, neighbours, strangers and authoritative figures like police officer, teacher and nurse; and 3) state level actors that produces incompetent legislation and practices incoherency in bureaucratic system that leads to obfuscation in implementation. However, the study has its limitation whereby the findings may not be generalised to other groups such as that of upper or lower class, as well as inter-ethnic marriages between citizens and non-citizens.

The existence of external challenges as identified in the present paper is believed to have its roots in the issue of organising social differences in the society according to ethnic lines. Societies in East Malaysia are more fluid and diverse in such context, thus inter-ethnic marriage is not seen as a threat to its social structure. Whereas the society in the Peninsular has been divided into four distinct ethnic categories, with each ethnic category is assumed to have homogenous membership with matching identity, and not affected in its interaction with other ethnic categories. Such categorisation was in fact, required in order to make a society better managed. Ethnic categorisation is often conjured to existence according to the perspective of members who hold authoritative power or influence in the society. This perspective is referred to by Shamsul (1996) as 'authority-defined' social reality. The four ethnic categories system as implemented in the Peninsular Malaysia, does not translate well in the practical realm on everyday life, especially where inter-ethnic marriage is concerned. In another realm of social reality namely the 'everyday-defined' (Shamsul, 1996), metaphysical existence of categorisation of society members cease to exist as inter-ethnic interaction occurs on the individual and personal level from an internal point of view, i.e., as one member of an ethnic group to another member of an ethnic group (Jenkins, 2000).

In the context of inter-ethnic marriage, external challenges arise when generalisation, stereotype and blanketed identification of ethnic categorisation that occurs in tandem with authority-defined approach, overwhelms the complexity, diversity and fluidity that exist in the social reality. As such, the existence and mobility of social groups in between the categories have been little understood and largely ignored, thus marginalised. The findings also reveal that interaction between couples and children of inter-ethnic marriage with wider society were often dictated by negative stereotype and prejudice towards the former. On the interpersonal level, members of the mainstream society were often ignorant and insensitive towards the uniqueness of inter-ethnic marriages, whilst on the institutional level, legislation and bureaucratic system were ill-equipped and incoherent in providing a fair and clear approach in organising and providing social support system to inter-ethnic couples and their children. 
Challenges become more complicated when inter-ethnic marriages occur between partners whose ethnic group they are member of, are not of equal standing in legislation, be it civil or Islamic family law as occurs in Malay-non-Malay marriages. Taking into consideration of gradual increase of inter-ethnic marriage trend in Malaysian society due to increasing ethnic contact and connectedness via globalisation, migration and mobilisation, the findings strongly reveal that there is an unavoidable task to work on a lot of aspects in order to enable the society in the Peninsular Malaysia to move beyond the narrow and hierarchical approach of organising its society into four exclusive and rigid ethnic categories to facilitate the acceptance and acknowledgment of the practice of inter-ethnic marriages in the society. Nevertheless, the uphill task, if it is addressed wisely, would ensure the promotion of social cohesion in the society towards nation-building in the long run.

\section{Acknowledgements}

The present paper is an output from a research funded by National Unity and Integration Department (JPNIN) under Prime Minister's Department, Malaysia (Research Grant RE-008-2010). In addition, the authors would also like to thank fellow research members Kartini Aboo Talib@ Khalid and Phoon Li Juan@ Roovasini for their contributions to this research.

\section{References}

Ang, L. H., \& Shik, P. Y. (2010). A Pilot Study on Language Identity of Chinese-Indian Mixed Race Children in Malaysia. Paper presented at Malaysia International Conference on Foreign Languages (MICFL 2010), organised by Faculty of Modern Languages and Communication, Universiti Putra Malaysia, 1-2 December 2010, Serdang, Selangor.

Baharuddin, R., Juhari, R., \& Tan, J. P. (2003). Perkahwinan campur di Malaysia. Serdang: Penerbit Universiti Putra Malaysia.

Chong, B. S. Y. (2009). A note on Malaysians of mixed parentage. Malaysian Journal of Economic Studies, 46(1), 93-95. Retrieved from http://www.myjurnal.my/filebank/published_article/13957/MixParentage.pdf

Fernandis, G. (2000). Papia, relijang e tradisang: Tshe Portuguese Eurasians in Malaysia: Bumiquest, a search for self-identity. Lusotopie, 2000, 261-269.

Fujimoto, H. (1988). The South Indian Muslim community and the evolution of the Jawi Peranakan in Penang up to 1948. Tokyo: ILCCA Tokyo Gaikokugo Daigaku.

Hak, N. A. (2012). Rights of a wife in the case of conversion to Islam under Family Law in Malaysia. Arab Law Quarterly, 26(2), 227-239. http://dx.doi.org/10.1163/157302512X629214

Hassan, S. Z. S. (2005). History and the indigenization of the Arabs in Kedah, Malaysia. Paper presented at the Yemeni-Hadramis in Southeast Asia: Identity Maintenance of Assimilation? Organised by The Department of History and Civilisation of the Kulliyyah of Islamic Revealed and Human Sciences, International Islamic University Malaysia (IIUM), 26-28 August 2005, Kuala Lumpur.

Ismail, R. (2003). An evaluation of marital relationship and its implications for cross cultural counselling of Kadazandusun and Sino-Kadazan couples in Sabah, Malaysia. Asia Pacific Journal of Social Work and Development, 13(1), 99-116. http://dx.doi.org/10.1080/21650993.2003.9755915

Jalil, Z. (2010, February 26). Waspada kahwin campur. Utusan Malaysia. Retrieved from http://www.utusan.com.my/utusan/info.asp?y=2010\&dt=0226\&pub=Utusan_Malaysia\&sec=Muka_Hadapa n\&pg=mh_01.html

Jenkins, R. (2000). Categorization: Identity, social process and epistemology. Current Sociology, 48(3), 7-25. http://dx.doi.org/10.1177/0011392100048003003

Lindenberg, J. (2009). Interethnic marriages and conversion to Islam in Kota Bharu. In G. W. Jones, H. L. Chee, \& M. Mohamad (Eds.), Muslim-non-Muslim marriage: Political and cultural contestations in Southeast Asia (pp. 219-254). Singapore: Institute of Southeast Asian Studies.

Mac, Y. S., \& Zaid, A. R. M. (2010). The language choice in different domains among Chindians in Malaysia. Paper presented at International Conference on Minority and Majority: Language, Culture and Identity, organised by Centre for Language Studies, Universiti Malaysia Sarawak, 23-24 November 2010, Kuching, Sarawak.

Minuddin, B. (2005, June 22). Perkahwinan campur orang Melayu wajar dipantau. Utusan Malaysia. Retrieved from 
http://www.utusan.com.my/utusan/info.asp?y=2005\&dt=0622\&pub=utusan_malaysia\&sec=forum\&pg=fo_ 02.htm\&arc $=$ hive

Mohamad, M., Aziz, Z., \& Oy, S. C. (2009). Private lives, public contention: Muslim-non-Muslim family disputes in Malaysia. In G. W. Jones, H. L. Chee \& M. Mohamad (Eds.), Muslim-non-Muslim marriage: Political and cultural contestations in Southeast Asia (pp. 59-101). Singapore: Institute of Southeast Asia Studies.

Mohamed, N. (2009). Bahasa Melayu kreol Chetti Melaka: Deskripsi leksiko-fonologi. Pulau Pinang: Penerbit Universiti Sains Malaysia.

Moorthy, R. (2009). The evolution of the Chitty of Melaka. Jebat, 36, 1-15. Retrieved from http://www.ukm.my/jebat/images/upload/Ravichandran\%20Moorthy\%2036.pdf

Nagaraj, S. (2009). Intermarriage in Malaysia. Malaysian Journal of Economic Studies, 46(1), 75-92. Retrieved from http://www.myjurnal.my/filebank/published_article/13956/Intermariage.pdf

Osman, S. (1981). Perkahwinan antara etnik: Satu kajian di Bandar Melaka. Akademika, 19, 29-38.

Phang, F. A. (2011, December 18). Changing religion, not ethnicity. New Straits Times. Retrieved from http://www.nst.com.my/opinion/columnist/changing-religion-not-ethnicity-1.20881

Pue, G. H., \& Shamsul, A. B. (2011). Discourse on 'Peranakanness' with focus on the Peranakan Chinese community in contemporary Kelantan, Malaysia. Paper presented at the International Conference on Humanitites, Societies and Culture (ICHSC 2011), organised by International Economics Development and Research Center (IEDRC), 6 November 2011, Kuala Lumpur. Retrieved from http://www.ipedr.com/vol20/47-ICHSC2011-M10035.pdf

Shamsul, A. B. (1996). Debating about identity in Malaysia: A discourse analysis. Southeast Asian Studies, 34(3), 476-499.

Shamsul, A. B. (1999). Identity contestation in Malaysia: A comparative commentary on 'Malayness' and 'Chineseness'. Akademika, 55, 17-37.

Sintang, S., Khambali, K. M., Baharuddin, A., \& Ahmad, M. (2011). Interfaith marriage and religious conversion: a case study of Muslim converts in Sabah, Malaysia. Paper presented at International Conference on History and Society Development (ICHSD 2011), organised by International Economics Development and Research Center (IEDRC), 25-27 November 2011, Maldives.

Tan, C. B. (1982). Peranakan Chinese in northeast Kelantan with special reference to Chinese religion. Journal of the Malaysian Branch of the Royal Asiatic Society (JMBRAS), 55, $26-52$.

Tan, C. B. (1988). The Baba of Melaka: Culture and identity of a Chinese Peranakan community in Malaysia. Petaling Jaya: Pelanduk Publications.

Tan, C. B. (2002). Chinese minority in a Malay state: The case of Terengganu in Malaysia. Singapore: Times Media Private Limited.

Tan, J. P. (2012). Inter-ethnic and mono-ethnic families: Examining the association of parenting and child emotional and behavioural adjustment. Pertanika Journal of Social Science and Humanities, 20(1), 165-178.

Tan, P. C. (1989). Perkahwinan campur etnik di Semenanjung Malaysia. In A. S. Cheek (Ed.), Cabaran Malaysia tahun lapan puluhan (pp. 235-243). Kuala Lumpur: Persatuan Sosial Sains Malaysia.

Tan, Y. S. (2011). Akulturasi Peranakan Cina di Tirok, Terengganu. Jurnal Terjemahan Alam \& Tamadun Melayu, 2(2), 151-162.

Tang, A. R. (2005). Arab Hadramis in Malaysia: A study of their origins and their assimilation in the Malay society, organised by The Department of History and Civilisation of the Kulliyyah of Islamic Revealed and Human Sciences, International Islamic University Malaysia (IIUM), 26-28 August 2005, Kuala Lumpur.

Teo, K. S. (2003). The Peranakan Chinese of Kelantan: A study of the culture, language and communication of an assimilated group in Malaysia. London: Asean Academic Press.

Yap, E. M. (1989). Komuniti Ceti Melaka: Satu pengenalan. Jurnal Antropologi dan Sosiologi, 17, 55-72.

Yusoff, O., \& Aziz, J. (Eds.). (2010). Jawi Peranakan di Pulau Pinang: Ekspresi sebuah identiti. Pulau Pinang: Penerbit Universiti Sains Malaysia. 
Zainon, Z. (2005, June 21). Keistimewaan kahwin campur: Lahirkan zuriat yang baik. Utusan Malaysia. Retrieved from http://www.utusan.com.my/utusan/info.asp?y=2005\&dt=0621\&pub=Utusan_Malaysia\&sec=Bicara_Agama \&pg=ba_03.html

Zakaria, N. M. (2010, February 27). Kahwin campur memang ada risiko. Utusan Malaysia. Retrieved from http://www.utusan.com.my/utusan/info.asp?y=2010\&dt=0227\&pub=Utusan_Malaysia\&sec=Dalam_Negeri $\& \mathrm{pg}=\mathrm{dn} \_17 . \mathrm{html}$

\section{Notes}

Note 1. For further readings on various Peranakan communities in Malaysia, please refer among others, Tang (2005), Fernandis (2000), Fujimoto (1988), Moorthy (2009), Mohamed (2009), Yusoff \& Aziz (2010), Pue \& Shamsul (2011), Hassan (2005), C.B. Tan (1982, 1988, 2002), Y.S. Tan (2011), Teo (2003), and Yap (1989).

\section{Copyrights}

Copyright for this article is retained by the author(s), with first publication rights granted to the journal.

This is an open-access article distributed under the terms and conditions of the Creative Commons Attribution license (http://creativecommons.org/licenses/by/3.0/). 